\title{
Dynamics of heat shock proteins quantity in rats' gastric mucosa lysates upon chronic atrophic gastritis development
}

\author{
S. Ya. Mandryk ${ }^{1,2}$, L. N. Gaida ${ }^{1}$, L. N. Kapustian ${ }^{2}$, I. O. Tikhonkova ${ }^{2}$, O. V. Drobinska ${ }^{1}$,
}

L. L. Sidorik ${ }^{2}$ L. I. Ostapchenko ${ }^{1}$

${ }^{1}$ National Taras Shevchenko University of Kyiv

64, Volodymyrska Str, Kyiv, Ukraine 01033

${ }^{2}$ Institute of molecular biology and genetics NAS of Ukraine

150, Zabolotnogo Str, Kyiv Ukraine, 03680

Sergman83@mail.ru

\begin{abstract}
The levels of Hsp60, Hsp70 and Hsp90 in rats' gastric mucosa cells lysates upon the development of experimental chronic atrophic gastritis (CAG) were investigated by the immunoblot-analysis. The quantities of Hsp60 and Hsp70 at the early (the first two weeks) and late (the 5-6 ${ }^{\text {th }}$ weeks) stages of disease progression were reliably higher in comparison with normal mucosa. It was also observed an increase in Hsp90 expression at the end of the first week of CAG. The increase in Hsp expression in gastric mucosa was shown upon activation of apoptosis, generation of reactive oxygen species, and gastric atrophy development.
\end{abstract}

Keywords: chronic atrophic gastritis, atrophy, heat shock proteins.

Introduction. The structural abnormalities in certain cellular proteins are considered as one of the possible reasons of origin and pathogenesis of certain human diseases (for example certain neurodegeneration).

It is known, that some cellular proteins (particularly the proteins with relatively low molecular mass) having been synthesized in ribosomes can independently acquire native spatial conformation which is energetically the most stable one [1]. It was demonstrated by Asfinsen in experiments with ribonuclease [2]. However, the large amount of proteins, required in order to provide the correct spatial conformation, demands the participation of special proteins so called molecular chaperones or heat shock

(C) S. Ya. MANDRYK, L. N. GAIDA, L. N. KAPUSTIAN, I. O. TIKHONKOVA,

O. V. DROBINSKA, L. L. SIDORIK, L. I. OSTAPCHENKO, 2008 proteins. The participation and molecular mechanisms of chaperones expression during the progression of such gastrointestinal tract diseases such as stress ulcer, chronic gastritis, stomach and duodenum polyps, cancer of various esophagus segments etc., require more profound research [3-5]. Moreover, one of the cardinal problems of chaperone functioning in cells of gastrointestinal tract mucosa is the study of their participation in regulation of molecular mechanisms of apoptosis and proliferation [5-7].

Therefore the objective of this work was to study the contents of Hsp60, -70 and -90 proteins, as well as those of Bax and Ki-67, in rats' gastric mucosa cell lysates at different stages of chronic atrophic gastritis (CAG).

Materials and methods. All experiments with rats have been done accordingly the guidance on the 
medico-biological studies on animals in accordance to the European Convention. The nonlinear white rat males with the initial mass of $180-220 \mathrm{~g}$ were used. For 6 weeks $2 \%$ sodium salicylate ( $2 \mathrm{ml}$ intragastrically) was injected into animals, and drinking water was replaced by $20 \mathrm{mM}$ sodium deoxycholate solution.

The levels of proteins expression, antioxidative enzymes activity and TBK-active products concentration (TBK-AP - lipids oxidation products, which form the complexes with thiobarbituric acid) in gastric mucosa homogenate were estimated at $1^{\text {st }}, 2^{\text {nd }}$, $3^{\text {rd }}, 4^{\text {th }}, 5^{\text {th }}$ and $6^{\text {th }}$ weeks of experimental pathology development [8].

Gastric mucosa cells were lyzed in the PIPA buffer

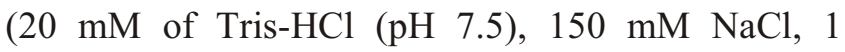
micromole EDTA, $1 \%$ Triton X-100, and proteinase inhibitors cocktail).

The protein concentration was determined by the Bradford method [9]. The lysate proteins were analyzed by PAGE-electrophoresis under denaturing conditions in accordance to Laemmli method [10]. The immunoblotting of received samples was carried out in accordance to [11].

The quantitative processing of immunoblotting results was carried out applying the program TotalLab.

Polyclonal antibodies against Hsp90 and Hsp60 were obtained by the method, described in [12]. The Hsp90 preparation, purified from the bull brain, was kindly provided by Professor Ya. Kuznitsky (International Institute of Molecular and Cell Biology, Poland). Polyclonal antibodies against DnaK (prokaryotic analogue of eukaryotic Hsp70) were received from Professor N. Pfanner (University of Freiburg, Germany).

The content of TBK-AP was estimated by the method of Stalnaya and co-authors [13]. The method is based on the ability of malonic dialdehyde to form complexes with thiobarbituric acid. The TBK-AP concentration was determined by spectrophotometry on wavelength $l=532$ nanometre.

The activity of superoxide dismutase (SOD) was determined in accordance to Chevary at all [14]; the catalase activity - in accordance to Koroluk et al [15].

Software package "STATISTICA for Windows 5.1" was applied for statistical pessing of results. Statistical pessing was carried out on the basis of 3-4 independent experiments. The value $\mathrm{p}<0.05$ was considered as a criterion of difference validation.

Results and discussion. The study of possible involvement of heat shock proteins role in gastric mucosa protection under conditions where CAG turns into stomach cancer is rather problematical from both medical and biological points of view. One of the reasons is the polyetiology of chronic gastritis (CG). Thus, more than $70 \%$ of all CG cases is associated with Helicobacter pylori infection; $15-18 \%$ is the share of autoimmune gastritises, caused by antibodies against certain proteins of parietal cells; about $10 \%$ is connected with consuming nonsteroidal anti-inflammatory drugs; less than $5 \%$ of (reflux gastritises), caused by bile refluxes from duodenum, and up to $1 \%$ is the share of so-called rare forms of chronic gastritis, which include eosinophilic, lymphocytic chronic gastritis etc. [16]. Temporal dynamics of atrophy is complicated and can last 17-30 years.

In accordance to the classical investigations of Correa, chronic gastritis can turn into stomach cancer through a number of interrelated stages [17, 18]. Therefore the search for the adequate experimental model of this disease is one of the main tasks in the study of molecular mechanisms of stomach cytoprotection. We applied the CAG experimental model, developed in the works of Vang et al [8]. The CAG progression in rats was caused by daily oral administration of $2 \%$ sodium salicylate and drinking water substitution by $20 \mathrm{mM}$ sodium deoxycholate solution. Sodium salicylate immediately damages the mucus barrier of stomach [6-8]. Besides, sodium salicylate is an inhibitor of E-class prostaglandins synthesis enzyme (prostaglandin cyclooxygenase). E-class prostaglandins, particularly $\mathrm{PGE}_{2}$, belong to the humoral factors involved in stomach enteytes protection [8]. The mucous membrane injuries caused by the influence of sodium deoxycholate are similar to those caused by the influence of bile acids salts. The latters get into the stomach from duodenum during bile refluxes and can damage the native structure of stomach membrane lipoproteids $[8,16]$.

The mass infiltration of mucous membrane by neutrophils, the decline of quantity of digestive glands in antral segments and mucin layer thinning during the 
The concentration of TBK-active products and antioxidant enzymes activity in rats' gastric mucosa cell lysate upon chronic atrophic gastritis $(C A G)$ development.

\begin{tabular}{c|c|c|c}
\hline Weeks of CAG development & $\begin{array}{c}\text { The activity of SOD, } \\
\text { arb. units. } \mathrm{min}^{-1} \mathrm{mg} \mathrm{of} \mathrm{protein}^{-1}\end{array}$ & $\begin{array}{c}\text { The catalase activity, } \\
\mathrm{nmol}_{2} \mathrm{O}_{2} \mathrm{~min}^{-1} \mathrm{mg}_{\text {of }} \text { protein }^{-1}\end{array}$ & $\begin{array}{c}\text { The TBK-AP concentration, } \\
\text { nmol-mg of protein }\end{array}$ \\
\hline Control & $0,192 \pm 0,016$ & $7,22 \pm 0,64$ & $94,92 \pm 8,26$ \\
1 & $0,138 \pm 0,013^{*}$ & $9,21 \pm 0,87^{*}$ & $179,98 \pm 15,85^{*}$ \\
2 & $0,086 \pm 0,008^{*}$ & $5,27 \pm 0,51^{*}$ & $104,7 \pm 9,61$ \\
3 & $0,067 \pm 0,006^{*}$ & $4,92 \pm 0,36^{*}$ & $142,83 \pm 13,75^{*}$ \\
4 & $0,058 \pm 0,005^{*}$ & $7,56 \pm 0,69$ & $124,83 \pm 12,08^{*}$ \\
6 & $0,125 \pm 0,011^{*}$ & $6,39 \pm 0,58$ & $150,44 \pm 14,27 *$ \\
& $0,118 \pm 0,009^{*}$ & $6,39 \pm 0,62$ & $150,7 \pm 13,83^{*}$
\end{tabular}

Note: Statistical pessing of the results was carried out on the basis of 3-4 experiments. *the value is statistically reliably differs from the control value by $\mathrm{p}<0.05$

$6^{\text {th }}$ week of experimental pathology, were observed by Vang et al [8]. Besides, during the $6^{\text {th }}$ week of CAG development the abnormal spherical fair-sized cells were revealed in gastric mucosa, which could be linked with intestinal metaplasia development [8]. Thus the proposed model of CAG agrees with the morphological picture of reflux gastritis with transition into intestinal stomach dysplasia.

Starting from the $1^{\text {st }}$ week of CAG model, the concentration of TBK-AP in the lysate of mucous membrane, was rising statistically reliably, in comparison with control value (see the table). TBK-AP are generated as a result of interaction between the products of malonic dialdehyde lipids peroxidation (LPO) and thiobarbituric acid [13, 19]. The activation of LPO pesses, regardless from the induction factor, can cause destructive changes in cells which are associated with oxidation products accumulation. The LPO products (malonic dialdehyde, free radicals of fatty acids and the hydroperoxides of higher fatty acids residues) are able to inactivate the membrane enzymes, disturb the protein-lipid interactions in membranes, create intermolecular linkages, change the lipidic fraction viscosity etc. [13, 19-21]. The level of LPO production is normally controlled by a number of antioxidative substances (vitamins $\mathrm{E}$ and $\mathrm{C}$, ubiquinone etc.) and enzymes (SOD, catalase, glutathione peroxidase etc.) $[13-15,19-21]$.
It was observed that SOD activity in the gastric mucosa lysate was statistically reliably decreasing, starting from the $1^{\text {st }}$ week of disease model development (see table). The activity of catalase was significantly decreased during the $2^{\text {nd }}$ and $3^{\text {rd }}$ weeks of CAG (see the table). The decrease of SOD and catalase activity in certain stages of model along with the rise of TBK-AP concentration was identified. The later ones and the mucous membrane antioxidative potential decay could suggest the progress development development of oxidative stress. The rise of the reactive oxygen species (ROS) levels and the activation of LPO pess in tissues were demonstrated for many hepatopathies, arthritises, atherosclerosis, some infectious diseases etc. Moreover, the proteins oxidation and the cell aggregates formation are associated with the activation of LPO-pesses [13, 19, 20].

The activation of inflammatory process in gastric mucosa may be one of the possible reasons of the TBK-AP rise during the model CAG development [19]. The histological study on gastric mucosa at different stages of CAG were accomplishrd. The level of mucous membrane infiltration by neutrophils was found to increase at the end of the $3^{\text {rd }}$ week of the disease progression. At the same time the gastric mucosa thickened, that can indicate the intensification of tissue regeneration and proliferation in response to the injection of salicylate and sodium dioxycholate. 

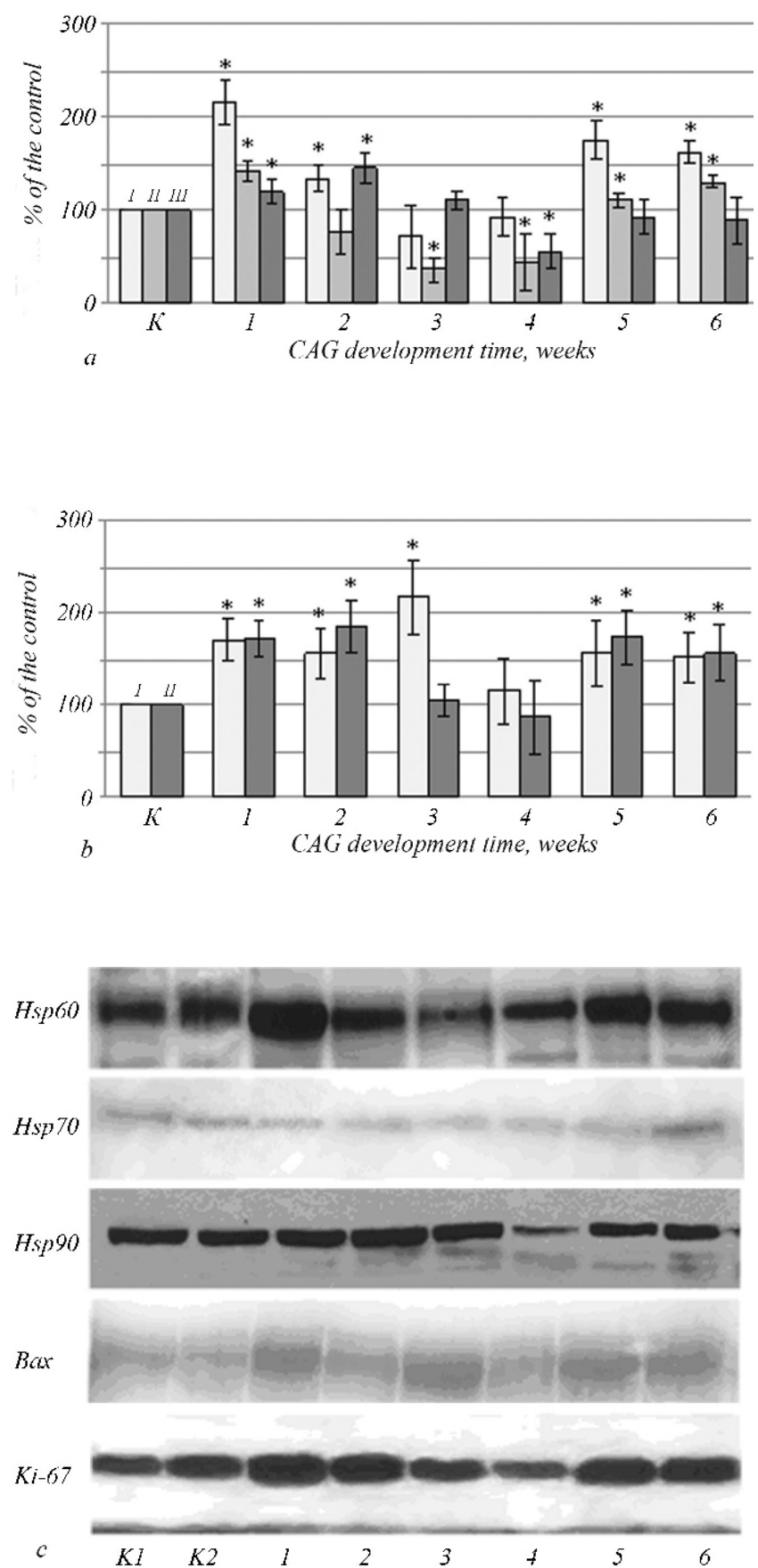

The Hsp 60 (1a) Hsp70 (2a) Bax (1b) and Ki-67 (2b) level detected by western-blot analysis at chronic athrophic gastritic development

During the $5^{\text {th }}$ and $6^{\text {th }}$ weeks the mucous membrane thinning was observed in the histological sections of stomach tissues. The membrane was partially replaced by connective tissue evidencing for atrophy (data is not cited).
The content of Bax pro-apoptotic protein and marker of proliferation protein $\mathrm{Ki}-67$ were determined in the lysate of gastric mucosa cells. The Figure $(b)$ shows that the amount of Bax protein was increased already during the $1^{\text {st }}$ week while the maximum Bax content was observed at the $3^{\text {rd }}$ week of CAG development. As mentioned above, the mucous membrane thinning and its partial replacement by connective tissue were revealed at the final stages of disease which may result in the reduction of digestion glands quantity (atrophy). It is known that one of the reasons of atrophy is the die-off of digestion gland cells, particularly parietal cells, producing hydhloric acid $[16,18]$. The rise of TBK-AP concentration, starting from the $1^{\text {st }}$ week of CAG development (see the table), indicates that the intensification of ROS generation can be a possible explanation for apoptosis and stomach atrophy progressing.

Ki-67 protein appeared in the cell nucleus at the end of G1 phase of cell cycle. A possible role of Ki-67 is binding with chromatin that may be important for the regulation of cell division. The level of Ki-67 expression may be used to ascertain a mitotic index of the transformed cells [22]. Maximum Ki-67 content, reliably higher than control value, was observed during the $1^{\text {st }}, 2^{\text {nd }}, 5^{\text {th }}$ and $6^{\text {th }}$ weeks of CAG (Fig., $b$ ).

Thus, the obtained results indicate the intensification of lipids damage by free radicals, inflammatory development, activation of apoptosis and proliferation in the rat gastric mucosa at certain stages of experimental disease .

We studied the dynamics of the main chaperons in the gastric mucosa cells at experimental CAG. The Hsp60 and Hsp70 content the lysate of mucous membrane cells was rising at the end of the $1^{\text {st }}$ week as well as during the $5^{\text {th }}$ and $6^{\text {th }}$ weeks of the CAG development. The reliable decrease in Hsp70 content was observed during the $3^{\text {rd }}$ and $4^{\text {th }}$ weeks. The level of Hsp90 protein was higher in comparison with control value during the $1^{\text {st }}$ and $2^{\text {nd }}$ weeks and it decreased in the end of the $4^{\text {th }}$ week of experimental disease progression (Fig. $a$ ).

The definition of CAG was finally formulated in 1998 as programmed loss of the stomach glands and/or their replacement by the intestinal glands and epithelium of intestinal type (gastrointestinal 
metaplasia). The CAG course is often closely associated with the development of stomach cancer, therefore $\mathrm{CAG}$ is referred to precancerous conditions. In accordance with the classical works of Correa the stomach cancer development includes gradual CAG transition into intestinal metaplasia, dysplasia and intestinal adenocarcinoma [17].

In general, a disbalance between proliferation and apoptosis in the gastric mucosa epithelial cells is typical for the CAG progression and behavior. As stated above, the heat shock proteins, particularly Hsp70 and Hsp60, belong to the cellular molecular chaperons. They are responsible for the support of correct spatial conformation of many cell proteins and refolding or proteolysis depending on various stress conditions (denaturating factors, elevated temperature, intracellular dyscrasia etc.) [16-18].

Under stress conditions the chaperons expression irrupts, which obviously indicates the cytoprotective function of these proteins. However, the chaperons are also expressed at rather high level under physiological conditions to insure newly synthesized cellular proteins maturation. The expression of certain chaperons, particularly Hsp73, Hsp60 and Hsp27, in actively proliferating cells is increased, first of all, due to uprise of protein synthesis and respectively their requirement for folding, refolding and irreversibly denatured polypeptides degradation $[1,5]$.

The control on correct folding of cellular proteins seems to be a key role of HSP in the protection of mucous membrane. It has been mentioned, that from the first weeks of CAG progression the mucous membrane is infiltrated by neutrophils and lymphocytes which indicates the inflammatory process in stomach tissues. The intensified ROS generation is one of the consequences of mucous membrane infiltration by activated neutrophils [16]. The TBK-AP content rise in cells may be an evidence for elevated ROS generation (see the table). An increase in the level of such ROS as superoxide anion, hydroxyl radical and hydrogen peroxide in the stomach cells upon CG progression can indicate the decay in SOD and catalase activity involved in their neutralization.

Thus, it is known that SOD catalyzes the superoxide anion dismutation, generating hydrogen peroxide which is reduced to water by catalase [19, 20]. The rate of ROS generation in the cells can vary depending on the metabolism state and increases upon the cell dyscrasia above all. Such ROS as hydrogen peroxide and hydroxyl radical are able to modify proteins and perturb their active conformation $[19,21]$. Thus, the role of molecular chaperons at CAG is evidently a control on the quality of stomach cell proteins.

Conclusion. The increase in Hsp60, Hsp70 and Hsp90 content has been demonstrated in the rat gastric mucosa at the certain stages of experimental CAG development. This is obviously an indication of their involvement in the cytoprotection at the development of oxidative stress and activation of apoptosis and proliferation in the gastric mucosa.

С. Я. Мандрик, Л. М. Гайда, Л. М. Капустян, І. О. Тихонкова, О. В. Дробінська, Л. Л. Сидорик, Л. І. Остапченко

Динаміка зміни вмісту білків теплового шоку в лізаті клітин слизової оболонки шлунка щурів під час розвитку експериментального хронічного атрофічного гастриту

Резюме

Методом імуноблотингу досліджено вміст білків теплового шоку Hsp60, Hsp70 i Hsp90 в лізаті клітин слизової оболонки шлунка щурів за умов розвитку експериментального хронічного атрофічного гастриту (ХАГ). Вміст білків Hsp60 і Hsp70 статистично достовірно підвищувався на ранніх (1-й, 2-й тижні) і пізніх (5-й, 6-й тижні) етапах розвитку моделі захворювання. Рівень білка Нsp90 зростав на 1-й тиждень ХАГ. Показано, що збільшення вмісту шаперонів спостерігається під час активації процесів апоптозу, генерації активованих форм кисню і розвитку атрофії илунка.

Ключові слова: хронічний атрофічний гастрит, атрофія, білки теплового шоку.

С. Я. Мандрык, Л. Н. Гайда, Л. Н. Капустян, І. О. Тихонкова, О. В. Дробинская, Л. Л. Сидорик, Л. И. Остапченко

Динамика изменения количества белков теплового шока в лизате слизистой оболочки желудка крыс в условиях развития экспериментального хронического атрофического гастрита

Резюме

Методом иммуноблотинга исследовано количество белков теплового шока Hsp60, Hsp70 и Hsp90 в лизате клеток слизистой оболочки желудка крыс в условиях развития экспериментального хронического атрофического гастрита (ХАГ). Количество белков Нsp60 и Нsp 70 статистически достоверно повышалось на ранних (1-я, 2-я недели) и поздних (5-я, 6-я недели) этапах развития заболевания. Уровень белка Нsр90 возрас- 
тал в первую неделю ХАГ. Показано, что увеличению количества шаперонов сопутствует активация процессов апоптоза, генерации активированых форм кислорода и развития атрофии желудка.

Ключевые слова: хронический атрофический гастрит, атрофия, белки теплового шока.

\section{REFERENCES}

1. Fink A. L. Chaperone-mediated protein folding // Phys. Rev.-1999.-79.-P. 425-449.

2. Anfinsen C. B. Principles that govern the folding of protein chains // Science.-1973.-181.-P. 223-230.

3. Ciocca D. R., Calderwood S. K. Heat shock proteins in cancer: diagnostic, prognostic, predictive, and treatment implications // Cell Stress Chaperones.-2005.-10.-P. 816103.

4. Malago J. J., Koninkx J. F. G., Dijk J. E. The heat shock response and cytoprotection of the intestinal epithelium // Cell Stress Chaper.-2002.-7.-P. 191-199.

5. Oksala N. K. J., Oksala A., Paavonen T., Alhava E., Paimela $H$. Heat shock preconditioning modulates proliferation and apoptosis after superficial injury in isolated guinea pig gastric mucosa via an eicosanoid and protein synthesis-dependent mechanism // APMIS.-2003.-111.-P. 497-506.

6. Rokutan K. Gastric mucosal protection and cell proliferation. Role of heat shock proteins in gastric mucosal protection // J. Gastroenterol. Hepatol.-2000.-15.-P. 12-19.

7. Tsukimi Y., Okabe S. Recent advances in gastrointestinal pathophysiology: role of heat shock proteins in mucosal defense and ulcer healing // Biol. Pharm. Bull.-2001.-24.P. 1-9.

8. Wang L.-J., Chen S.-J., Chen Z., Cai J.-T., Si J.-M. Morphological and pathologic changes of experimental chronic atrophic gastritis $(\mathrm{CAG})$ and regulating mechanism of protein expression in rats // J. Zhejiang Univ. SCIENCE B.-2006.-7.-P. 634-640.

9. Bradford M. M. A rapid and sensitive method for the quantitation of microgram quantities of protein utilizing the principle of protein-dye binding // Anal. Biochem.-1976.72.- P. 248-254.

10. Laemmli $U$. K. Cleavage of structural proteins during the assembly of the bacteriophage T4 // Nature.-1970.-227.P. 680-685.
11. Bollag D. M., Rozycki D. M., Edelstein S. J. Protein methods.-New York, 1996.-415 p.

12. Капустян Л. Н., Киямова Р. Г., Гришкова В. С., Терентьев А. Г., Филоненко В. В., Сидорик Л. Л. Получение рекомбинантного шаперона GroEL и его иммунологическая кросс-реактивность с Нsp60 // Біополімери і клітина.2006.-2, № 22.-C. 117-120.

13. Барабой В. А., Орел В. Э., Карнаух И. М. Перекисное окисление и радиация.-Київ: Наук. думка, 1991.-178 с.

14. Чевари С., Чаба И., Секей И. Роль супероксиддисмутазы в окислительных процессах клетки и метод определения ее в биологических материалах // Лаб. дело.-1985.№ 11.-С. 578-681.

15. Королюк М. А., Иванова Л. И., Майорова И. Г., Токарев В. $E$. Метод определения активности каталазы // Лаб. дело.1988.-№ 1.- С. 16-19.

16. Григор'єв П. Я., Стародуб С. М., Яковенко Е. П., Гаврилюк М. С., Шостак С. С. Хвороби органів травлення (Діагностика і лікування).-Тернопіль: Укрмедкнига, 2000.-102 c.

17. Correa $P$. The epidemiology and pathogenesis of chronic gastritis: three etiologic entities // Front. Gastrointest. Res.1980.-6.-P. 98-108.

18. Fox J. G., Wang T. C. Inflammation, atrophy, and gastric cancer // J. Clin. Inv.-2007.-117.-P. 60-69.

19. Владимиров М. В., Арчаков А. И. Перекисное окисление липидов в биологических мембранах.-М.: Наука, 1972.$78 \mathrm{c}$.

20. McCord J. M., Edas M. A. SOD, oxidative stress and human pathologies: a brief history and a future vision // Biomed. Pharmacol.-2005.-59.-P. 139-142.

21. Lushchak V. I., Gospodaryov D. V. Catalases protect cellular proteins from oxidative modification in Saccharomyces cerevisiae // Cell Biol. Int.-2005.-29.-P. 187-192.

22. Тихонкова I. О., Лізогубов В. В., Хожаєнко Ю. В., Довгопола О. О., Коровін С. І., Овчаренко Г. В., У сенко В. С., Роднін М. В., Філоненко В. В. Дослідження структурно-функціональних властивостей імуногенного фрагмента Кі-67 антигену та отримання до нього полі- і моноклональних антитіл // Біополімери і клітина.-2005.-21, № 2.C. $180-183$. 